\title{
Mapping the Linguistic Politeness of Dusun Tangkuru Society: The Pattern of Politeness in Makassar
}

\author{
Novalia Tanasy, A. Muhajir Nasir, and Nur Indah Rara Yulianti \\ Universitas Muslim Maros, Turikale, Indonesia \\ nurindahrara@gmail.com
}

\section{ARTICLE HISTORY \\ Received : 25 August 2020 \\ Revised : 26 August 2020 \\ Accepted : 27 September 2020}

\section{KEYWORDS}

Politeness

Society

Makassar Language

Sociolinguistics

\begin{abstract}
This study aims to reveal events or facts, circumstances, phenomena, variables and circumstances that occur during the research by presenting what happened and know the politeness of the language used by Dusun Tangkuru society when interacting with Makassar society. This research uses a descriptive qualitative research method, with a form of descriptive data presentation. Data obtained through the interview process. The data source is taken from Dusun Tangkuru society. Based on the results of research on mapping the language politeness of Dusun Tangkuru society towards Makassar language, it was found that there was a level of politeness used by the Tangkuru hamlet community. Not only that, the researchers also found that there were factors that influenced the pattern of politeness of Dusun Tangkuru society towards Makassar language which could be caused by social factors such as stratification, distance and kinship.
\end{abstract}

\section{Introduction}

Interaction is necessary in society as a human being. Humans interact and communicate with each other by using language. Through language, a person can express their ideas, feelings, and desires. Occasionally they require words related corresponding such as informal words, slang, humans or respective language (Derin et al., 2019). Aristoteles in Astuti (2017: 1) stated that "humans are social beings. The truth is that every human in the world needs to interact with each other, and indeed interaction is significant in social life. Humans interact with each other in society using their respective language.

Politeness is a requirement in every distinguishing life (Yusuf \& Anwar, 2019). Politeness is about making a great relationship with auditor and adviser. Politeness is a key for showing the auditor or interlocutor about values for mutual respect (Hamuddin \& Wardi, 2017). Politeness needed in social purposes for make interaction process well (Sapitri et al., 2020). The example of politeness in society is when local community starts to communication in society (Alam \& Al-Muthmainnah, 2020). Communication will show society capability in argued statements to other people, explain the facts, found new information, anyway communicate with each other, to tell something related information.

Sociolinguistics is study related all to aspects in society, which are the related field that study the relationship of social life in society such as the language used by the community, customs, culture, rules in society and other social aspects that exploring the sector of language and society and having close correlations with the social sciences, especially social psychology, anthropology, human geography and sociology (Hasanah et al., 2019; Prihandoko et al., 2020).

Sociolinguistics covers all aspects of problem related to social science in society. Sociolinguistics provides information related to language science, how language is used in social terms, to create a harmonious relationship in society even though there are many diverse cultures. That is why it is imperative to learn about sociolinguistics. Knowledge about sociolinguistics can help someone to get information and understanding related to their desires by studying the language in a social context.

Politeness is the rules and direction in showing attitude, behaviour, and action. Politeness is an important part of sociolinguistics because someone must pay attention when do and say something. For a long time, several researchers have an interest in politeness lessons. Politeness has been studied since 1960 from various studies. Watts in Sudjirman (2016: 39) stated Politeness is an irresistible study of discourse which has caused quite a lot of debate and differences of opinion since the early 1970s. In this case, politeness is one of the important sciences to learn that is related to language. But it can also create disputes among the community since the beginning, it depends on the perspective and thinking of the people themselves.

Yassi (2017) stated politeness is a powerful communication strategy to avoid conflicts between individuals and groups of people on a larger scale such as conflicts between groups, between villages or between ethnic groups. In the process of interaction between individuals, politeness has a social function, one of which is 
to create a process of peaceful and harmonious interaction to avoid problems. This study refers to three social variables, including power $(\mathrm{P})$ which refers to social status or power, then distance (D) which refers to the level of closeness of the speech participants, and kinship (K) which refers to the level of kinship.

There are two types of politeness accompanied by action, namely positive politeness, and negative politeness. Positive politeness is an attitude and the way a person shows a bond of friendship when speaking with the speaker through the perspective of a close relationship of intimacy by maintaining the relationship between the speaker and the participant and accepts each other as well as various attitudes by showing positive values that contain mutual respect between the interlocutor and announcer.

Negative politeness is the attitude and manner of someone who shows the distance of a relationship due to several different factors. This can be seen when someone shows and adds strength to the speaker and sticks to the position. In general negative politeness is associated with rejection but does not interfere with freedom from someone.

Society is a unit of community groups that settle together in an area, in which contained rules and systems through interactions that are intertwined in communication between individuals and other individuals.

Language is an ability possessed by humans to interact with other humans. Which is, a communication tool to convey information and express feelings. In this world, there is not only one language but there are thousands of languages, spread all over the world. In other word languages is the product of a culture.

The local language is the language that is owned by the local community in an area or can be said as the regional language used by the community in a particular region in a country. However, it cannot be said as an official language, for example, the country of Indonesia, although it has hundreds of languages, the official language is Indonesian, so every Indonesian citizen must know the Indonesia language. The goal is as a unifying tool for the nation. Although still there is a citizen in Indonesia who have not mastered even the language of Indonesia. However, there is certainly a language they mastered that is their own regional languages, for example, Javanese, Sundanese, Buginese, makassarese, and other languages.

Makassar language or basa mangkasara' is a language used by the Makassar tribe, the Makassar language has its alphabet called the alphabet/letter lontara. Makassar language has its role for the Makassar tribe to convey what is in their minds. Yamaguchi in Sudjirman (2016:47) Stated that Makassar is the second most common language in the South-Sulawesi Language Group. Besides Muhtamar in Sudjirman (2016:47). Makassar ethnic covers some territories: Makassar, Gowa, Takalar, Jeneponto, a half part of Bantaeng, Selayar, a half part of Maros, and a half part of Pangkep.

\section{Method}

In this research, researcher used a qualitative descriptive method. Qualitative research is research that is used to investigate, discover, describe, and explain the quality or features of social influence that cannot be explained, measured or illustrated through a quantitative approach. In this research, the researcher followed up analysed and presented the actual data. Based on situations and conditions that have occurred, the purpose of this study is to find out the facts and phenomena that occur based on situations and conditions that occur during researchers conducting research, based on existing facts.

The total sample in this study is six people. The sample was chosen by using the accidental sampling technique. In collecting the data, the researcher used a recording, noting, and interviews directly methods. The research recorded in every activity Dusun Tangkuru society during the interaction process. Then the researcher made an important note of all activities that was regarded as important when using politeness during the interaction.

There was some technique used to complete this research. First, researcher observed the interaction of community communication when the interaction processed taken placed, whether the community uses negative politeness or positive politeness. Second, the researcher conducted a direct interview with the Dusun Tangkuru society to find out how polite the speech was used when communicating. Then recorded the results of public communicated through interviewed used mobile phone as recorded devices. The researcher also noted some important information obtained from interviewed. After all the data were completed, the researcher analysed all the data and gathered all of them to get some important points related to the research. With that data the researcher concluded and wrote the results into the study.

\section{Results \& Discussion}

Table 1 shows the respondents' initials, age, occupations and social influence within the society.

Table 1. Dusun Tangkuru's Respondents

\begin{tabular}{cccc}
\hline Respondents & Age & Job & $\begin{array}{c}\text { Social } \\
\text { Influence }\end{array}$ \\
\hline MDN & 47 & $\begin{array}{c}\text { Peasant woman } \\
\text { and housewife } \\
\text { farmer }\end{array}$ & kinship \\
SDL & 33 & $\begin{array}{c}\text { Stratification } \\
\text { stratification }\end{array}$ \\
SPN & 50 & $\begin{array}{c}\text { kindergarten } \\
\text { teacher }\end{array}$ & distance \\
HDP & 33 & School operator & distance \\
HN & 22 & Online reseller & kinship \\
MAL & 18 & Student & distance \\
SN & 21 & student &
\end{tabular}




$\begin{array}{cccc}\text { H } & 40 & \begin{array}{c}\text { housewife } \\ \text { Housewife and } \\ \text { peasant woman }\end{array} & \begin{array}{c}\text { stratification } \\ \text { stratification }\end{array} \\ \text { AH } & 39 & \text { student } & \text { distance } \\ \text { MHJ } & 20 & \text { Village Staff } & \text { kinship } \\ \text { MR } & 19 & \text { Student } & \text { kinship } \\ \text { SDS } & 45 & \text { Housewife } & \text { stratification } \\ \text { NI } & 15 & \text { student } & \text { kinship } \\ \text { SNA } & 15 & \text { student } & \text { distance } \\ \text { SP } & 22 & \text { student } & \text { distance } \\ \text { IT } & 61 & \text { Housewife and } & \text { stratification } \\ & & \text { peasant women } & \\ \text { HA } & 30 & \text { Village staff } & \text { kinship } \\ \text { HN } & 23 & \text { Student } & \text { kinship } \\ \text { AY } & 24 & \text { student } & \text { distance }\end{array}$

\subsection{Level of Politeness of Dusun Tangkuru Society Towards Makassar Language. $\underline{\text { MDN }}$}

Date : 12 May 2020

MDN is a housewife and peasant woman at the age of 47, from the results of interviewing MDN, there was a level of politeness that was used when speaking.

\section{$\underline{\text { SDL }}$}

Date : 13 May 2020

SDL is a farmer he is 33 years old, from the results of interviewing SDL. There was a level of politeness that he used when interacting,

\section{SPN}

\section{Date : 13 May 2020}

SPN is one of the reputable and respected people because she had a degree of syarifa or puang, she is 50 years old, SPN is a kindergarten teacher. from the results of SPN interviewed, there was a level of politeness that was used when interacted.

\section{HDP}

\section{Date : 15 Mei 2020}

HDP is a school operator in one of the elementary schools in Dusun Tangkuru, 33 years old. From the results of interviewed HDP, there was a level of politeness that she used when interacting with the interviewer.

\section{$\underline{\text { HN }}$}

Date : 16 Mei 2020

HN is a widow and also as online seller, aged 22 years, from the results of interviewing $\mathbf{H N}$, there was a level of politeness that she used when interacting.

\section{$\underline{\text { MAL }}$}

Date : 11 June 2020

MAL is the biological child of MDN, she is 18 years old, MAL is a student. From the results of interviewing MAL, there was a level of politeness that she used when interacting with the interlocutor.

\section{$\underline{\text { SN }}$}

\section{Date : 18 August 2020}

SN is a student, she is 21 years old, from the results of interviewing SN. There was a level of politeness that she used when interacting.

\section{$\underline{\mathbf{H}}$}

Date

\section{: 18 August 2020}

$\mathbf{H}$ is a housewife, she is 40 years old,_from the results of interviewing $\mathrm{H}$. There was a level of politeness that she used when interacting.

\section{$\underline{\mathrm{AH}}$}

Date : 18 August 2020

AH is a student, she is 18 years old,_from the results of interviewing AH. There was a level of politeness that she used when interacting.

\section{$\underline{\text { NDB }}$}

NDB is a housewife and peasant woman, she is 39 years old, from the results of interviewing NDB. There was a level of politeness that she used when interacting.

\section{$\underline{\text { MHJ }}$}

MHJ is a village staff, he is 20 years old, from the results of interviewing MHJ. There was a level of politeness that he used when interacting.

\section{$\underline{\text { MR }}$}

MR is a student, he is 19 years old, from the results of interviewing MR. There was a level of politeness that he used when interacting. 


\section{$\underline{\text { SDS }}$}

SDS is a housewife, she is 45 years old,_from the results of interviewing $\mathbf{S N}$. There was a level of politeness that she used when interacting.

\section{NI}

NI is a student, she is 15 years old, from the results of interviewing NI. There was a level of politeness that she used when interacting.

\section{$\underline{\text { SNA }}$}

SNA is a student, she is 15 years old, from the results of interviewing SNA. There was a level of politeness that she used when interacting.

\section{$\underline{\text { SP }}$}

SP is a student he is 22 years old, from the results of interviewing SP. There was a level of politeness that she used when interacting.

\section{$\underline{\text { IT }}$}

IT is a housewife and peasant woman, she is 61 years old, from the results of interviewing IT. There was a level of politeness that she used when interacting.

\section{$\underline{\text { HA }}$}

HA is a village staff she is 30 years old,_from the results of interviewing HA. There was a level of politeness that she used when interacting.

\section{$\underline{\mathrm{HN}}$}

HN is a student, she is 23 years old,_from the results of interviewing $\mathbf{H N}$. There was a level of politeness that she used when interacting.

\section{$\underline{\mathrm{AY}}$}

AY is a student, she is 24 years old,_from the results of interviewing AY. There was a level of politeness that she used when interacting.

\subsection{Factors Which Influence The Pattern Of Politeness Of Dusun Tangkuru Society Towards Makassar Language}

\section{$\underline{\text { MDN }}$}

\section{Date : 12 May 2020}

From the result of interviewed MDN, there was several things that can affected the pattern of politeness, this is evidenced by the response of the participant when the researcher conducted an interviewed. there were several factors that affected the pattern MDN politeness when speaking with someone.

\section{$\underline{\text { SDL }}$}

\section{Date : 13 May 2020}

From the results of SDL interviewed, there were several things that affected politeness patterns, this is evidenced by the participant response when the researcher conducted an interviewed. There were several factors that affected the pattern of participant politeness, namely the stratification, distance and kinship factors.

\section{$\underline{\text { SPN }}$}

\section{Date : 13 May 2020}

From the results of SPN interviewed, there was several things that affected the pattern of politeness, this is proven by the participant response when the researcher conducted interviewed. There were several factors that affected the participant politeness pattern, that is the distance and kinship factors.

\section{HDP}

\section{Date : 15 May 2020}

From the interviewed results, there were several things that affected the HDP politeness pattern, this is proved by the participant's response when the researcher conducted interviewed. There were several factors that can affected HDP politeness patterns, namely, stratification, distance, and kinship.

\section{$\underline{\mathrm{HN}}$}

\section{Date : 16 May 2020}

From the results of interviewed $\mathbf{H N}$, there was a number of things that can be affected the pattern of participant E, politeness. This is due to the participant's response when the researcher conducts interviewed. From the interviewed results there were several things that affected the pattern of HN politeness. 


\section{Date : 11 June 2020}

From the results of MAL interviewed, there was several things that can affected the pattern of politeness, this is evidenced by the responses of the participant when the researcher conducted an interviewed.

\section{$\underline{\text { SN }}$}

From the result of interviewed $\mathbf{S N}$, there was several things that can affected the pattern of politeness, this is evidenced by the response of the participant when the researcher conducted an interviewed. there were several factors that affected the pattern $\mathbf{S N}$ politeness when speaking with someone.

\section{$\underline{\mathbf{H}}$}

From the result of interviewed $\mathbf{H}$, there was several things that can affected the pattern of politeness, this is evidenced by the response of the participant when the researcher conducted an interviewed. there were several factors that affected the pattern $\mathbf{H}$ politeness when speaking with someone.

\section{$\underline{\mathrm{AH}}$}

From the result of interviewed $\mathbf{A H}$, there was several things that can affected the pattern of politeness, this is evidenced by the response of the participant when the researcher conducted an interviewed. there were several factors that affected the pattern $\mathbf{A H}$ politeness when speaking with someone.

\section{$\underline{\text { NDB }}$}

From the result of interviewed NDB, there was several things that can affected the pattern of politeness, this is evidenced by the response of the participant when the researcher conducted an interviewed. there were several factors that affected the pattern NDB politeness when speaking with someone.

\section{$\underline{\text { MHJ }}$}

From the result of interviewed $\mathbf{M H J}$, there was several things that can affected the pattern of politeness, this is evidenced by the response of the participant when the researcher conducted an interviewed. there were several factors that affected the pattern MHJ politeness when speaking with someone.
From the result of interviewed MR, there was several things that can affected the pattern of politeness, this is evidenced by the response of the participant when the researcher conducted an interviewed. there were several factors that affected the pattern MR politeness when speaking with someone.

\section{$\underline{\text { SDS }}$}

From the result of interviewed SDS, there was several things that can affected the pattern of politeness, this is evidenced by the response of the participant when the researcher conducted an interviewed. there were several factors that affected the pattern SDS politeness when speaking with someone.

\section{NI}

From the result of interviewed NI, there was several things that can affected the pattern of politeness, this is evidenced by the response of the participant when the researcher conducted an interviewed. there were several factors that affected the pattern NI politeness when speaking with someone.

\section{SNA}

From the result of interviewed SNA, there was several things that can affected the pattern of politeness, this is evidenced by the response of the participant when the researcher conducted an interviewed. there were several factors that affected the pattern SNA politeness when speaking with someone.

\section{$\underline{\text { SP }}$}

From the result of interviewed SP, there was several things that can affected the pattern of politeness, this is evidenced by the response of the participant when the researcher conducted an interviewed. there were several factors that affected the pattern SP politeness when speaking with someone.

\section{$\underline{\text { IT }}$}

From the result of interviewed IT, there was several things that can affected the pattern of politeness, this is evidenced by the response of the participant when the researcher conducted an interviewed. there were several factors that affected the pattern IT politeness when speaking with someone. 
From the result of interviewed HA, there was several things that can affected the pattern of politeness, this is evidenced by the response of the participant when the researcher conducted an interviewed. there were several factors that affected the pattern MDN politeness when speaking with someone.

\section{$\underline{\mathbf{H N}}$}

From the result of interviewed $\mathbf{H N}$, there was several things that can affected the pattern of politeness, this is evidenced by the response of the participant when the researcher conducted an interviewed. there were several factors that affected the pattern $\mathbf{H N}$ politeness when speaking with someone.

\section{$\underline{\mathrm{AY}}$}

From the result of interviewed $\mathbf{A Y}$, there was several things that can affected the pattern of politeness, this is evidenced by the response of the participant when the researcher conducted an interviewed. there were several factors that affected the pattern $\mathbf{A Y}$ politeness when speaking with someone.

\section{Conclusion}

Based on the results of the study entitled "mapping the language politeness of Dusun Tangkuru society towards Makassar language" It can be concluded that two main things are the answers to the formulation of the problem namely. From the results of the six participant interviews, there are kevels difference of politeness that used when interacting which is caused by social factors such as stratification, distance, and kinship. These social factors can cause the six participants to use different levels of politeness. From the results of the six participant interviews there are several factors that can affect politeness patterns, this is evidenced by the responses of the participant, these factors include stratification, distance and kinship.

This research is an initial research for the writer. So there are still many mistakes in the preparation of research. Therefore there are some suggestions submitted, namely that the researcher hope that the results of this study can provide knowledge and understanding related to how to talk to the other person using polite language. Hopefully this research can provide benefits in addition to new insights and references for future researchers.

\section{References}

Alam, F. A., \& Al-Muthmainnah, A.-M. (2020). Exploring Local Wisdom in Buginese Ethnics: Language Politeness Phenomena of Tau Soppeng. REiLA : Journal of Research and Innovation in Language, 2(1), 14-18.
Astuti, H. B. (2017). The use of politeness strategies in the conversation between Ben Whittaker and Jules Ostin in the intern movie. yogyakarta: shanata dharma university.

(Online)(https://repository.usd.ac.id/9340/2/1112140 82_full.pdf., accessed 13 October 2019.

Derin, T., Deliani, S., Fauziah, N., Afifah, N., \& Hamuddin, B. (2019). Indonesians' Tendency to Refer Abbreviation as Acronym: Types of Abbreviation as Word Formation Process. Globish: An English-Indonesian Journal for English, Education, and Culture, 8(2).

Hamuddin, B., \& Wardi, J. (2017). Playing with Politeness in Economic Journals: The Strategy Used by Authors to Bring about Solidarity and Respect.

Hasanah, L., Pradina, S., Hadita, A., \& Putri, W. C. (2019). Sociolinguistic Influence in the Use of English as a Second Language (ESL) Classroom: Seeing from OGO's Perspective: . Elsya : Journal of English Language Studies, 1(1), 28-32. https://doi.org/10.31849/elsya.v1i1.2538

Prihandoko, L. A., Tembang, Y., Marpaung, D. N., \& Rahman, F. (2019, October). English language competence for tourism sector in supporting socioeconomic development in Merauke: A Survey Study. In IOP Conference Series: Earth and Environmental Science (Vol. 343, No. 1, p. 012170). IOP Publishing.

Sapitri, P. A., Chasanah, A., Putri, A. A., \& Paulima, J. (2020). Exploring Brown and Levinson's Politeness Strategies: An Explanation on the Nature of the Politeness Phenomenon. REiLA : Journal of Research and Innovation in Language, 1(3), 111117. https://doi.org/10.31849/reila.v1i3.3801

Sudjirman, F. (2016). Politeness strategies used by makassar-bugis lecturers in english language teaching. makassar: state university of makassar. (Online)(https://pdfs.semanticscholar.org/98f5/cf648 ba432d33cba2444a227c2b6b583d147.pdf., accessed5 October 2019).

Yassi, A. H. (2017). Ancangan model kerangka teori kesantunan yang efektif mengkaji budaya bahasabahasa heritage di Asia: Review terhadap keuniversalitasan kerangka teori kesantunan Brown \& Levinson. Linguistik Indonesia, 35(2), 159-186.

Yusuf, R., \& Anwar, A. (2019). An Article Review on "The Use of Politeness Strategies in the Classroom Context by English University Students\&quot;. Elsya : Journal of English Language Studies, 1(2), 69-73. https://doi.org/10.31849/elsya.v1i2.3530 https://doi.org/10.31849/reila.v2i1.3767 